\title{
Disaster Management in Industrial Areas: Perspectives, Challenges and Future Research
}

\author{
Yousuf A.M.A. Rebeeh (D), Shaligram Pokharel ${ }^{*}$ D, Galal M. Abdella iD, Abdelmagid S. Hammuda (iD \\ Department of Mechanical and Industrial Engineering, Qatar University (Qatar) \\ y.rebeeb@qapco.com.qa, Correspondingauthor: shaligram@qu.edu.qa,gmg5005@qu.edu.qa, Hamouda@qu.edu.qa
}

Received: June 2018

Accepted: January 2019

\begin{abstract}
:
Purpose: In most countries, development, growth, and sustenance of industrial facilities are given utmost importance due to the influence in the socio-economic development of the country. Therefore, special economic zones, or industrial areas or industrial cities are developed in order to provide the required services for the sustained operation of such facilities. Such facilities not only provide a prolonged economic support to the country but it also helps in the societal aspects as well by providing livelihood to thousands of people. Therefore, any disaster in any of the facilities in the industrial area will have a significant impact on the population, facilities, the economy, and threatens the sustainability of the operations. This paper provides review of such literature that focus on theory and practice of disaster management in industrial cities.
\end{abstract}

Design/methodology/approach: In the paper, content analysis method is used in order to elicit the insights of the literature available. The methodology uses search methods, literature segregation and developing the current knowledge on different phases of industrial disaster management.

Findings: It is found that the research is done in all phases of disaster management, namely, preventive phase, reactive phase and corrective phase. The research in each of these areas are focused on four main aspects, which are facilities, resources, support systems and modeling. Nevertheless, the research in the industrial cities is insignificant. Moreover, the modeling part does not explicitly consider the nature of industrial cities, where many of the chemical and chemical processing can be highly flammable thus creating a very large disaster impact. Some research is focused at an individual plant and scaled up to the industrial cities. The modeling part is weak in terms of comprehensively analyzing and assisting disaster management in the industrial cities.

Originality/value: The comprehensive review using content analysis on disaster management is presented here. The review helps the researchers to understand the gap in the literature in order to extend further research for disaster management in large scale industrial cities.

Keywords: disaster response, emergency management, disaster situation, decision-making

\section{To cite this article:}

Rebeeh, Y.A.M.A., Pokharel, S., Abdella, G.M., \& Hammuda, A.S. (2019). Disaster management in industrial areas: perspectives, challenges and future research. Journal of Industrial Engineering and Management, 12(1), 133-153. https://doi.org/10.3926/jiem.2663 


\section{Introduction}

Disaster refers to the event of serious interruption that leads to extensive losses of human lives and deterioration of the environment and physical facilities (Zio \& Aven, 2013). The disasters in industrial facilities are classified as technological disasters as they are essentially man-induced disasters (Granot, 1998). Van Wassenhove (2006) mentions that disaster disrupts the performance of existing systems, virtually to a standstill on its onset and threatens the systems' existence itself. Reniers, Khakzad, Cozzani and Khan (2018) mention that disaster in the industrial areas can happen not only due to the events inside the industry but also outside the industry, for example, natural disaster leading to flooding and fire in the chemical plants and events in other nearby plants leading to disaster event in the chemical industry. Therefore, the development of an inclusive disaster management to avoid a disastrous situation in the industrial cities becomes important (Shaluf, Ahmadun, Mat-Said, Mustapha \& Sharif, 2002). There have been guidelines prepared by the international agencies, such as that by the Organisation for Economic Co-operation and Development (OECD, 2003) and the United Nations Environment Programme (UNEP, 2010) for chemical disaster management. These guidelines focus on chemical accidents prevention. The review presented in this paper considers the research on disaster management in industrial cities (an area with many industrial facilities) as a whole; that means, it considers disaster related to both chemical and non-chemical processing industrial facilities in industrial cities.

Disasters occur in industrial cities due to the inadequacy of planning of response mechanism or sudden loss of control and functionality of the risk mitigation process. While many industries focus on internal risk-based management system to eliminate risks, disaster in industrial cities can be an external threat to a facility within or outside the industrial city. Inadequate planning, implementation of proper procedures for eliminating, reducing, reacting and recovering from disasters can create vulnerability of the industrial cities to disaster. As per the definition by Alexander (1997), vulnerability inherent in industrial cities can be economic (loss of a source of income to the people and the business owners) and technological (loss of capital assets). Alexander (1997) also mentioned that disaster management needs a multi-disciplinary approach with the inclusion of available technology and processes in it.

Chen, Chen and Li (2012) provided concepts on the lifecycle of disaster management system in which responses are classified into pre-incident, during the incident and post-incident stages. A similar classification is also provided by Moe and Pathranarakul (2006). Mojtahedi and Oo (2017) adopted this classification to review critical attributes of stakeholders in disaster management.

In pre-incident phase, the disaster management focuses on prediction, identification, and assessment. During the incident the focus is on the effective response, coping with the situation and fast recovery, and during post-incident, the focus is on complete recovery. The response mechanism for these phases are predictive (preventive), reactive and corrective (Mojtahedi \& Oo, 2017; Moe \& Pathranarakul, 2006). We follow this classification as well to discuss disaster management in industrial cities. The assumptions and considerations in each phase are briefly given below.

- Preventive (prediction) phase is an early stage management in which the focus is on response planning for avoiding or minimizing the impact of the disaster. This phase requires planners to simulate various disaster scenarios by considering intensity and spread of the impact in and around the industrial facilities. Therefore, this type of system needs to support quick data access, communication, selection of locations to stock the resources for mitigation of disaster impact, and deployment of resources at the quickest possible time. The main focus here is on the preparedness for all disaster situations.

- Reactive (response) phase is focused on relief supplies and other processes during or immediately after the occurrence of the disaster event in order to contain the damages and to minimize the impact of the event. A good response system gets activated immediately when a trigger for disaster is identified so that the impact can be contained as quickly as possible. The focus in this phase is to continuously monitor, control and provide all possible services as needed. Therefore, facilities and support developed for preventive phase become very important to deploy reactive phase activities. 
- Corrective (recovery) phase is focused on recovery after the occurrence of the disaster event. The main activities during this phase are recovery centered and support restoring the disaster inflicted situation to the equilibrium (as-was or better condition) through rehabilitation and reconstruction. Lesson learned from the disaster becomes a key to update preventive measures so that response system becomes more effective.

The review of literature shows that there is a need to strengthen the knowledge on the available tools for management of disaster in the industrial areas, particularly those with large facilities and handle highly reactive materials or compounds, and deal with risky procedures in processing such materials. The review shows that most of the literature focus on natural disaster although natural disaster may be one of the factors for industrial disaster. The systematic review and understanding on facilities planning, service system planning, resource planning for different type of industry and different type of incidents, and the modeling processes that can be adopted for a comprehensive disaster management is still lacking. Therefore, this review is expected to give a total overview of the industrial disaster management during different phases of disaster: preparedness, response and recovery.

\section{Methodology}

In this paper, the review is focused on the publication database such as books and journals available in the university, the published materials in databases maintained by ScienceDirect, Google Scholar, EmeraldInsight, and other database websites (such as Taylor and Francis, Wiley online, IEEExplore, Institute of Mechanical Engineers 'IMECHA', American Chemical Society 'ACS', and EBSCO). It is to note that some of the literature appeared in more than one database. This type of search of the literature for systematic review is consistent with that proposed by Benet-Zepf, Marin-Garcia and Küster (2018), Marin-Garcia and Martinez-Tomas (2016), and Marin-Garcia, Betancour and Giraldo-O’Meara (2018).

In this paper, content analysis method is used to extract the related information presented in the literature as it helps in developing a meaningful conclusion through the examination of the textual data in a large volume of the literature. Caunhye, Nie and Pokharel (2012) have also used content analysis to review optimization papers on emergency logistics and have mentioned that the analysis is helpful in identifying the relevance of literature on the focus of the study. Beerens and Tehler (2016) used content analysis on the disaster exercise related literature to obtain various attributes, such as forms, functions, purpose and the methods. Inoue and Havard (2015) mention that content analysis provides a quick method to analyze the accessible data to identify the forms required for the review.

The database was searched using keywords such as decision support system (DSS), emergency logistics, disaster management, industrial accidents, and emergency communication. The search and consequent review included the following.

- The framework, mathematical models, and applications of disaster management. The context of reviewed literature mainly focus on industrial disaster.

- Published articles (journals and conference proceedings) from 2000 to 2018. One basic paper published in 1997 that provides the emerging knowledge on the disaster is also reviewed.

- Published papers in English language for the detailed review.

The review excluded the papers before 2000, as preliminary search showed that the focus on disaster management and those particularly related to oil and gas industry are mainly considered after 2000 . The review also excluded the practitioner papers and books (or book chapters) as they may not have been peer-reviewed.

The analysis of the keywords search revealed that most of the papers on disaster management appeared in ScienceDirect database followed by the EmeraldInsight database. Of the collected literature, about $60 \%$ of the literature focused on the theoretical aspects while the rest focused on the applications and cases. Altogether, 71 literature were obtained but only 59 literature were found most relevant for this review. The findings from the analysis are presented in this paper. 
Similar to the techniques used by Benet-Zepf et al. (2018) and Marin-Garcia and Martinez-Tomas (2016), the literature review methodology used in this paper uses a streamlined and systematic process as shown in Figure 1. The search started with the keyword search and then examining the literature for their relevance in industrial disaster.
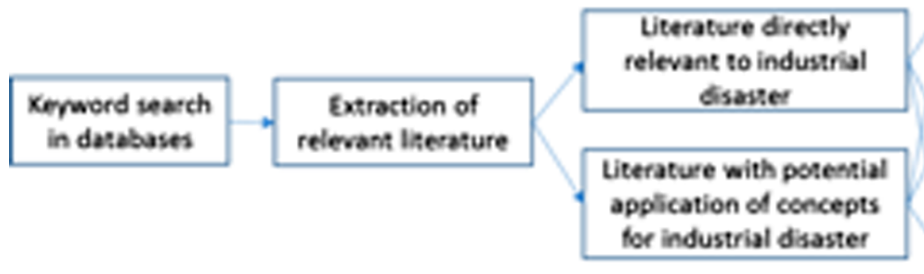
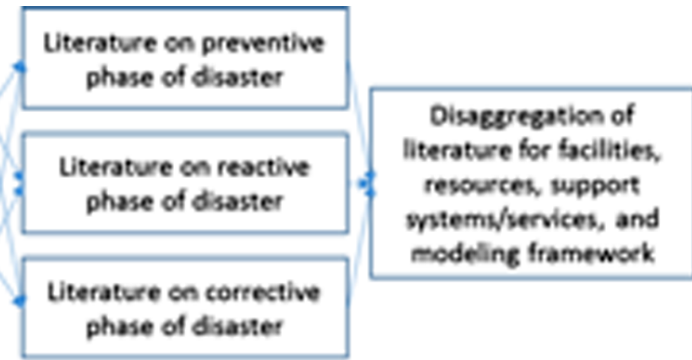

Figure 1. Methodology used for the literature review

Some of the reviewed literature are directly related to industrial disasters while the others mention of concepts that can be considered for the application and design of emergency system in industrial areas. The papers obtained from the search are then classified into different phases of disaster management as mentioned by Moe and Pathranarakul (2006). The authors mentioned prediction, emergency relief, rehabilitation, and reconstruction. The activities for these phases are considered as mitigation, preparedness, response, and recovery. For the purpose of review in this paper, the activities are grouped in terms of phases of disaster management as preventive, reactive, and corrective phases, as described above. As shown in Figure 1, the phases of disaster are further divided in to four sub-categories defined as facilities, resources, support systems and services, and modeling framework. The three sub-categories are further defined in terms of elements and described next. Modeling framework would encompass mathematical models or frameworks that are used in different phases of disaster management. This drilling down of the research in this way would help to bring the value of content analysis on literature review further.

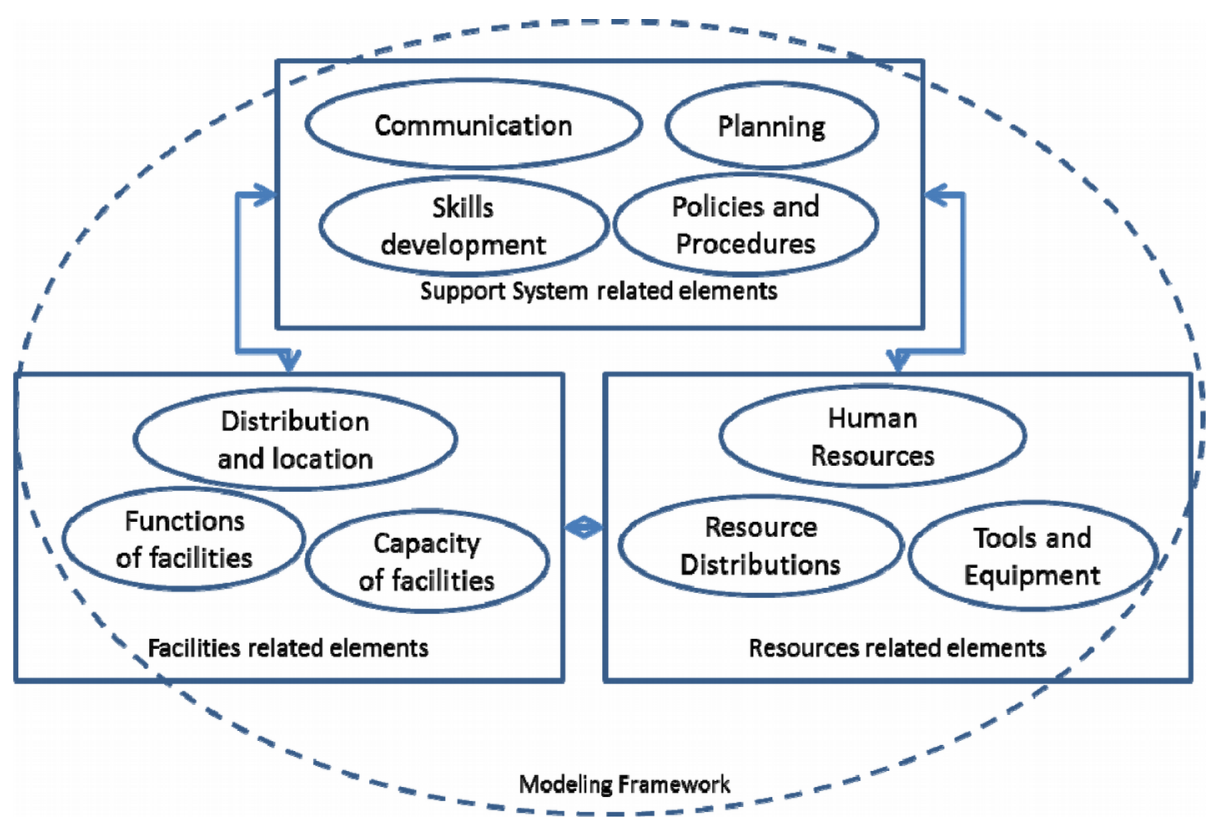

Figure 2. Sub-categories and elements in each phase of disaster response system

Facilities are described by elements: the location of facilities, capacities of these facilities, and their type of functions such as medical centers, hospitals, shelter camps, and warehouses. Resources are described by elements: human resources (such as rescue team, firefighting, safety, security, and medical personnel), tools and equipment 
(such as fire trucks, ambulance cars, rescue tools, or any other type of hardware) needed for the response management, software, and allocation of these resources. Support services or systems are described by elements: communications, policies and procedures, planning process and skills development. In communication, hardware and software systems such as GSM network, satellite mobile phones or information exchange system dedicated within the industrial areas are considered. In policies and procedures, documents in the form of paper or electronic medium that can be used for control, regulate and standardize the disaster management system are considered. In planning, the processes to develop clear actions, integrate them and evaluate them to find the fit of the plan with the response are considered. Finally, in training and skills development, skills enhancement or development for better utilization of tools, resources coordination as per plans, policies, and procedures are considered.

The rest of the paper is structured in two sections. Research on various types of disaster response mechanisms proposed and adopted by the researchers and practitioners are given in Section 2. In Section 3, main conclusions from the review are drawn and directions for research in the area of disaster management in industrial cities have been proposed.

\section{Literature Analysis}

The analysis of literature presented here is based on the grouping in terms of the phases of disaster management and the categories of these phases mentioned above. The frameworks and models used in different phases are also described in brief in the review. This is to note that some of the literature are cited in more than one phase because of the applicability of their content presented in different phases of disaster management.

\subsection{Preventive Phase}

Most of the literature in disaster or emergency management refers to the preventive phase. Planning of safety and security of industrial facilities is very important. Preventive phase planning can be very important specifically for the man-made disasters as incubation of the disaster may be imminent. Shaluf et al. (2002) mention that incubation period can be from a very short period to a very long period. The complacency in assuming everything to be in working condition, especially in the technological projects, can push away the need to plan for prevention. The authors give examples of short and long incubation periods causing major disasters in industries. This is to note that in the review presented here, the focus is on the provisions of measures to avoid or mitigate the disaster. The review below focuses on the subcategories mentioned in Figure 2 and the modeling framework that considers preventive phase.

\subsubsection{Facilities}

Facility location decision for preventive measures should include capacity, type, and accessibility to the disaster sites. Not only that, the design of industrial facilities and its contents (like materials storage) is also an important consideration. Various techniques such as analytic network process (ANP) or analytic hierarchical process (AHP) are used for risk assessment for the storage of hazardous chemicals or installations handling hazardous materials. The industries are prone to chemical spill and fire and therefore, hazard assessment of such facilities become important.

Zhao, Huang, Guo and Zhu (2008) used AHP and geographical information system (GIS) to assess the risk of facilities that use hazardous materials. They defined the facility based risk assessment in terms of intrinsic risk (such as property of substance and quantity of storage), derivative accident (such as impact on water pollution and traffic disruption), impact on surrounding environment (such as economic condition and population density) and rescue force (such as medical and fire forces). Therefore, site accessibility, economic impact, the number of people affected in a particular area, and readiness, capacity and skills of medical rescue force and fire safety force becomes important. The authors also use poison index (reflect the level of poisonous chemicals available on site), fire and explosion index (reflects chemicals substance nature from fire and explosion behavior) and erosion index (reflects chemicals substance nature from corrosion and erosion behavior) for their assessment.

Shen, Wang, Yan and Wang (2015) studied disaster situations due to a chemical spill. They studied the evacuation of people, location of shelters and routing of people to the shelters by considering two objectives: individual 
vulnerability (harm caused by the spill on individuals) and social vulnerability (harm caused to the population in an area and the location of the source of the spill). The three-stage solution methodology provides the best locations of shelter areas in the first stage, routing based on different factors in the second stage and the improvement in terms of the solution obtained in the third stage. The factors considered in the second stage are expanded further for evaluation in the third stage.

Khayal, Pradhananga, Pokharel and Mutlu (2015) mentioned that for large-scale disasters, installing temporary facilities and sharing resources among themselves are important. Such facilities could be set up for immediate relief to the affected people.

Davis, Samanlioglu, Qu and Root (2013) considered inventory prepositioning with a two-stage stochastic linear programming model in which the first stage is used for the prepositioning of supplies based on the forecasted impact of the disaster event. The authors considered the initial inventory at a location, the capacity of the facility, penalty cost for damaged supplies in the facility, distance from one supply point to another, the time allowed for prepositioning and the congestion in the traffic. The authors use scenarios to identify the worst-case demand (maximum demand) and worst-case supply (with the lowest level of available supply due to supply damage or loss of supply).

Li, Jin and Zhang (2011) developed a dual-step stochastic disaster preparedness model for relief supplies in the shelters. The authors used a two-stage optimization model by considering available resources, surplus or shortage of resources after evacuation in a particular shelter. In the first stage, the model uses the fixed cost of shelters and inventory cost of supplies in the shelters. In the second stage, the cost of transportation for evacuation and transportation of supplies, and the cost of surplus or shortage of supplies are minimized.

From the reviewed literature in this subsection, it can be mentioned that for the reduction of disaster impact, the routes, the location of shelters, impact on traffic due to disaster, the location of industrial facilities, the interaction of the facilities with the surroundings based on the type of chemical and the environmental factors are important. Further, it also shows that mathematical models such as single objective (or multi-objective) programming or analytical hierarchical programming in combination with other models can be used for decisions on facilities.

\subsubsection{Resources}

Seok, Nof and Filip (2012) proposed a sustainability-based DSS using collaborative control theory (CCT) for disaster management. The authors used three key factors, called protocols, for consideration in the DSS: disruption analysis -predict and manage disruption; negotiation management-understand and analyze stakeholders' objectives for negotiation, and; knowledge management—provide relevant data and information for decisionmaking and to maintain updated databases. The authors mentioned that for disruption analysis, demand fluctuations should be considered. For negotiation, options to get the supply from different manufacturers (or supplies) and any additional constraints should be considered. For knowledge management, the information on the requested amount, available capacity for transportation of the requested quantities, information on the location of manufacturers and the related costs should be considered. The authors have developed extensive mathematical models to analyze the decision situation.

Improvement of safety in a cluster of chemical plants is studied by Reniers, Ale, Dullaert and Soudan (2009). The authors mention that compared to the plant-level safety standards, for cluster level safety, cooperation, joint workforce planning, joint risks and hazard analysis, and joint planning for disaster response planning are required. This requires formal information exchanges in terms of documentation and feedback for safety enhancements. The framework should consider human resources, production, maintenance, and management and safety support. This framework can also help in defining and monitoring the responsibilities within the plant safety and cluster safety units. The authors also provide a list of 11 safety items that need to be considered in clusters.

The use of information systems has also been mentioned by Zhao et al. (2008). The authors recommended using a GIS-based system and AHP to aid in the planning of disaster management. Similarly, Yoon, Velasquez, Partridge and Nof (2008) mentioned of a computer-based DSS and Shaluf et al. (2002) developed an information-based framework for disaster management related planning activities. 


\subsubsection{Support System and Services}

Continuous training and skills development are important elements of disaster management support system. Shaluf et al. (2002) and Yoon et al. (2008) mentioned communication as one of the important aspects that can help in running the support system for disaster management smoothly.

Shaluf et al. (2002) observed that the level of emergency preparedness through the understanding of different causes of hazards are important in disaster management. The authors developed "Ibrahim-Razi" model by considering different phases of error accumulation leading to disaster. The authors mentioned that longer the incubation of error, larger is the impact of the disaster.

Yoon et al. (2008) mentioned that communication in disaster situations can be enhanced with a computerized model for group DSS (GDSS). Their GDSS used real-time information about available resources, communication contacts, maps, weather, plans and procedures to simulate real-life disaster situation.

The third element considers policies and procedures on disaster management support system. It is relatively a broad area which covers all important processes and sub-processes in the disaster response system. Generally, these procedures and communication protocols provide guidelines for groups and individuals on how to react, and whom to contact in case of disaster.

Calixto and Larouvere (2010) reviewed disaster response plans in Australia, Canada, Japan, United Kingdom, and the USA and mentioned that disaster plans can be categorized in terms of individual-level or site level (that focus on serious impact on individuals and the surrounding environment in a specific area), regional level (coordinated effort of multiple organizations, when an individual plan is not sufficient to cater to the needs for response), and national level (coordination of response and cooperation from multiple organizations on a larger scale). The authors developed sensitivity map and index to show criticality of a specific location and the location where critical resources are needed. The authors view that responses from the local government and the industries can be different and, therefore, good integration and coordination become necessary for an effective disaster response plan.

\subsubsection{Modeling Framework for Preventive Disaster Response}

Table 1 below provides the snapshot of different mathematical models and systems that are used for the prevention-based disaster management.

The researchers have used various mathematical or procedural frameworks in order to analyze the preventive aspects of the disaster management system. The authors have mostly considered a single objective programming based on mixed integer programming in order to arrive at either the location or location-allocation or location routing decisions. It is also found that decisions are made either through a single stage model or a multi-stage model. It is also seen that GIS, computer-based system, framework-based system or individual system can be used in disaster response.

\begin{tabular}{|l|l|l|l|l|l|l|}
\hline \multirow{2}{*}{ Authors } & \multicolumn{1}{|c|}{ Context } & Objectives used & $\begin{array}{l}\text { Single or } \\
\text { multiple } \\
\text { objective } \\
\text { functions }\end{array}$ & $\begin{array}{l}\text { Data types } \\
\text { Deterministic/ } \\
\text { Stochastic }\end{array}$ & \multicolumn{1}{c|}{$\begin{array}{l}\text { Solution } \\
\text { Method }\end{array}$} & $\begin{array}{c}\text { Information } \\
\text { system/ } \\
\text { Remarks }\end{array}$ \\
\hline $\begin{array}{l}\text { Calixto and } \\
\text { Larouvere } \\
(2010)\end{array}$ & $\begin{array}{l}\text { Chemical } \\
\text { disasters }\end{array}$ & - & - & Deterministic & Framework & $\begin{array}{l}\text { The cluster- } \\
\text { based } \\
\text { coordinated } \\
\text { disaster } \\
\text { response plan }\end{array}$ \\
\hline $\begin{array}{l}\text { Davis et al. } \\
(2013)\end{array}$ & Hurricane & $\begin{array}{l}\text { Prepositioning } \\
\text { cost }\end{array}$ & Single & Stochastic & $\begin{array}{l}\text { Single objective } \\
\text { programming in } \\
\text { two stages }\end{array}$ & - \\
\hline
\end{tabular}




\begin{tabular}{|c|c|c|c|c|c|c|}
\hline Authors & Context & Objectives used & $\begin{array}{l}\text { Single or } \\
\text { multiple } \\
\text { objective } \\
\text { functions }\end{array}$ & $\begin{array}{c}\text { Data types } \\
\text { Deterministic/ } \\
\text { Stochastic }\end{array}$ & $\begin{array}{l}\text { Solution } \\
\text { Method }\end{array}$ & $\begin{array}{l}\text { Information } \\
\text { system/ } \\
\text { Remarks }\end{array}$ \\
\hline $\begin{array}{l}\text { Khayal et al. } \\
\text { (2015) }\end{array}$ & $\begin{array}{l}\text { Generic } \\
\text { disasters }\end{array}$ & $\begin{array}{l}\text { Logistics and } \\
\text { deprivation costs }\end{array}$ & Single & $\begin{array}{l}\text { Stochastic } \\
\text { scenarios }\end{array}$ & $\begin{array}{l}\text { Single objective } \\
\text { programming, } \\
\text { multi-period } \\
\text { solution }\end{array}$ & - \\
\hline $\begin{array}{l}\text { Li et al. } \\
\text { (2011) }\end{array}$ & Hurricane & $\begin{array}{l}\text { Cost of capacity } \\
\text { and cost of } \\
\text { transportation }\end{array}$ & Single & $\begin{array}{l}\text { Stochastic } \\
\text { scenarios }\end{array}$ & $\begin{array}{l}\text { Stochastic Single } \\
\text { objective } \\
\text { programming in } \\
\text { two stages with } \\
\text { an L-shaped } \\
\text { algorithm }\end{array}$ & - \\
\hline $\begin{array}{l}\text { Reniers et al. } \\
(2009)\end{array}$ & $\begin{array}{l}\text { Chemical } \\
\text { industrial areas }\end{array}$ & - & - & Deterministic & $\begin{array}{l}\text { Framework- } \\
\text { safety } \\
\text { management }\end{array}$ & $\begin{array}{l}\text { Development } \\
\text { of cluster- } \\
\text { based safety } \\
\text { management } \\
\text { system }\end{array}$ \\
\hline $\begin{array}{l}\text { Shaluf et al. } \\
(2002)\end{array}$ & $\begin{array}{l}\text { Fireworks, } \\
\text { chemical, and } \\
\text { hazardous } \\
\text { materials } \\
\text { related } \\
\text { industries }\end{array}$ & - & - & Deterministic & Framework & $\begin{array}{l}\text { Development } \\
\text { of a model for } \\
\text { assessment of } \\
\text { technological } \\
\text { man-made } \\
\text { disaster }\end{array}$ \\
\hline $\begin{array}{l}\text { Seok et al. } \\
(2012)\end{array}$ & $\begin{array}{l}\text { Manufacturing } \\
\text { entities }\end{array}$ & - & - & Deterministic & $\begin{array}{l}\text { Collaborative } \\
\text { control theory }\end{array}$ & $\begin{array}{l}\text { Improvement } \\
\text { in DSS with } \\
\text { regard to } \\
\text { sustainability } \\
\text { on delivery } \\
\text { scheduling and } \\
\text { production } \\
\text { planning }\end{array}$ \\
\hline $\begin{array}{l}\text { Shen et al. } \\
(2015)\end{array}$ & $\begin{array}{l}\text { Chemical } \\
\text { industrial parks }\end{array}$ & $\begin{array}{l}\text { 1. Time } \\
\text { satisfaction } \\
\text { 2. The } \\
\text { probability of } \\
\text { using a route }\end{array}$ & $\begin{array}{l}\text { Weight- } \\
\text { based single } \\
\text { objective }\end{array}$ & Deterministic & $\begin{array}{l}\text { Compromise } \\
\text { programming for } \\
\text { transportation } \\
\text { and location }\end{array}$ & - \\
\hline $\begin{array}{l}\text { Yoon et al. } \\
(2008)\end{array}$ & $\begin{array}{l}\text { Generic, but } \\
\text { focus on the } \\
\text { transportation } \\
\text { network }\end{array}$ & - & - & Deterministic & Framework & $\begin{array}{l}\text { Development } \\
\text { of Group DSS }\end{array}$ \\
\hline $\begin{array}{l}\text { Zhao et al. } \\
(2008)\end{array}$ & $\begin{array}{l}\text { Chemical } \\
\text { installations }\end{array}$ & - & - & Deterministic & AHP & Use of GIS \\
\hline
\end{tabular}

Table 1. Modeling frameworks for preventive measures

It can be seen from Table 1 that most of the models are developed based on deterministic data. Mathematical models are also developed using the single objective programming method or analytical hierarchical programming. The reviewed papers focus mainly on routing, the location of facilities, evacuation, and developing a cluster (or group) based disaster response system.

\subsection{Reactive (Response) Phase}

Most of the literature that focuses on reactive phase focus on resources, distribution, and changes in demand situations. Some papers also discuss the temporary location of facilities and inter-facility transfer of supplies. 


\subsubsection{Facilities}

Location of facilities and distribution of the medical supplies using the rough set theory is illustrated by Wei, Qiuyan and Jinlong (2012). The authors considered various conditions, expert requirement (or a situation of disaster), and the feasibility of constructing the distribution facilities in various sites within the disaster area. The authors developed a decision table by considering different decision-making conditions in order to reduce the subsets of possibilities for the location of facilities and distribution of supplies. The paper uses different scenarios for decision-making inference, decision-making conditions, and three levels of possibility to construct a facility in a chosen location. This decision table and scenario analysis are used to prioritize the location of facilities in industrial cities.

Celik (2017) presented a method for location of temporary evacuation centers as a part of disaster operations management. The author developed 14 factors for selection of shelters based on the literature review. The author's integrated decision-making trail and evaluation laboratory (DEMATEL) method with interval type-2 fuzzy sets (IT2FSs) for facility analysis and found that the optimal distribution of relief is the most important factor for disaster management.

Khayal et al. (2015) show that both preplanning and positioning of resources can be done by anticipating the disaster. This means that in the industrial cities, a good planning by developing various disaster scenarios can help in pre-positioning the supplies in different places. However, during the event, not all areas may need all the supplies positioned at a particular place, therefore, inter-facility transfer of resources becomes important to quickly respond to the disaster situation.

Davis et al. (2013) also mentioned the need to account for demand changes and supply changes during the disaster. Although the spatial location of disaster in industrial cities may not be vast as that in the case of natural disasters, the changes do happen when there are delays in providing the relief services to the affected industrial facility or shelters. Provisions should be made to meet the demand in order to minimize the deprivation (Holguin-Veras, Jaller, Van Wassenhove, Pérez \& Wachtendorf, 2012).

\subsubsection{Resources}

Peng, Zhang, Tang and Li (2011) used multi-criteria decision-making system based on the quantity of resource losses in order to assess and rank the locations in a disaster. Although their three-stage model is developed for the agricultural situation, this model can be used in the industrial cities as well.

Lee, Wang, Wang and Cheung (2012) proposed an unstructured information management system (UIMS) framework to manage large databases of the disaster situation. In order to be able to effectively reduce the impact of disaster during the response phase, information of various forms like data, reports, speeches, images, and video should be analyzed. The authors proposed a three-tier framework for information input, the first tier is a feed-in layer for organizational information (emails and internal reports), the second tier is for outside information (like the websites of its associates and competitors), and the third tier is for a public thesaurus of the domain industry. The authors used synthesis evaluation to find the precision, usability, comprehensibility, reasonability, and usability of data and the associative information for an effective disaster response.

Ju, Wang and Liu (2012) mentioned that the emergency response capability of an organization refers to the processing capability of the department (for example, capability to command, collaboration with urgency), forecasting capability (for example, monitoring, warning, information system development and use), support capability (reserve available, communication, and simulating disaster plan), and after disaster processing capability (for example, social support and reconstruction). The authors mentioned that a scenario-based response system can help to reduce disaster impact.

Chen et al. (2012) proposed a conceptual framework for incident process assessment during the reactive phase. The framework considers three factors: possibility related, necessity related and other influence related. Possibility related factors consider the disaster type, current state and the evolutionary tendency of disaster, affected victims and property, and ability in terms of resource availability and supply of resources to the required areas. For necessity related, profit and value are considered. For influence related, the preference and tolerance of the decision 
making, and the emergency situations are considered. The authors divided the during incident assessment strategy into three measures: mitigability (the ability to reduce the impact of disaster through specific arrangements and precautions); rescuability (the potential to save lives and properties), and; recoverability (the potential and difficulties to bring the facilities to the normal or enhanced state of operation). The authors mention that proper assessment of these measures can provide an appropriate emergency response decision.

Baldini, Oliveri, Braun, Seuschek and Hess (2012) mentioned the use of radio frequency identification technology (RFID) to increase the efficiency of providing supplies in case of disaster. The authors mention that disaster incident in chemical installations have low predictability, medium impact, and the medium possibility of extension to different areas. The authors proposed a cryptographic algorithm to understand the flows correctly so that supplies can be coordinated for maximum impact. This requires a database with the quantity, type, and usability of the relief materials.

Immediate identification of disaster situation and mitigation planning has also been the subject of research. Zhong, Shi, Fu, He and Shi (2010) used Petri net-based disaster response framework to analyze and contain a situation like SARS (severe acute respiratory syndrome). In this case, tracking and information sharing becomes very important and the situation can be applicable to industrial disaster as well for meaningfully tracking each victim of disaster and providing required relief services.

Fancello, Mancini, Pani and Fadda (2017) considered the allocations of emergency vehicles for the response planning. They segregated emergency vehicles into three types in order to evacuate the victims according to their injury severity. The consideration of distance between the disaster area and the response facilities such as hospital and the anticipated congestion also becomes critical in a disaster situation. The choice of the vehicle types and their number changes when the level of severity changes dynamically during the response period. Therefore, correct assessment of the type and number of vehicles, dynamic condition of injury and the location and capacity of facilities becomes important in disaster management.

Yaming, Ming, Weidong and Hongkun (2011) proposed a DSS system that used GIS. The focus is on the chemical gas dispersion and blowouts that happen in petrochemical industries. The authors have mentioned that there is a need to develop a gas dispersion simulation model by considering wind speed and direction, production capacity, the content of the gas, surface roughness, and reference atmospheric pressure. Based on the simulated scenario, a simple static heuristic is used to identify a route for quick evacuation.

\subsubsection{Support System and Services}

Laakso and Palomäki (2013) mentioned that different usage of terminologies and languages in a disaster response can, in fact, increase the damage. In order to minimize this problem, the authors developed a theoretical framework and mentioned that horizontal level of communication spread across the organization becomes important to mitigate the impact of the disaster. The authors also mentioned the communication integration on the vertical levels so that the top level promotes collaboration on information exchange. The authors also mention that communication flow at the time of disaster and immediately afterward, communication at the event site, and the cooperation between relief works becomes important. They mention that cooperation is particularly important in industrial cities to warn the neighboring installation when an installation is exposed to a disaster risk. The use and integration of technology are important for such cooperation.

Reniers, Audenaert, Pauwels and Soudan (2011) have examined six chemical plants in which there are both fast shutdowns and slow shutdowns as a means to respond to the fire-induced risks from a nearby installation. The slow shutdown time in the companies varied from 15 minutes to 36 hours whereas that for fast shutdown time varied between 15 minutes to about 3 hours. Due to the high cost of shutdown, establishing and following proper policies and procedures become important.

\subsubsection{Modeling Framework for Reactive Disaster Response}

Table 2 below shows various modeling framework, from the mathematical model to framework-based models in order to develop the understanding of the disaster situation, response mechanism system, decision support and 
policy development for a common understanding of the disaster-related situations for tackling the during-incident situations. Although the coverage of the research is natural disasters to the generic type of disasters, the models mentioned are applicable to the industrial disasters as well. The review shows that most of the research publications for the reactive phase are based on the development and implementation of the framework.

\begin{tabular}{|c|c|c|c|c|c|c|}
\hline Authors & Context & $\begin{array}{l}\text { Objectives } \\
\text { used }\end{array}$ & $\begin{array}{l}\text { Single or } \\
\text { multiple } \\
\text { objective } \\
\text { functions }\end{array}$ & $\begin{array}{l}\text { Data types } \\
\text { Deterministic/ } \\
\text { Stochastic }\end{array}$ & Solution Method & $\begin{array}{c}\text { Information system/ } \\
\text { Remarks }\end{array}$ \\
\hline $\begin{array}{l}\text { Baldini et al. } \\
\text { (2012) }\end{array}$ & Generic & - & - & Deterministic & $\begin{array}{l}\text { A technology-based } \\
\text { framework for } \\
\text { efficient relief } \\
\text { supplies. }\end{array}$ & $\begin{array}{l}\text { Supports decision } \\
\text { making through a } \\
\text { prior understanding of } \\
\text { the needs and } \\
\text { development of } \\
\text { supply system to meet } \\
\text { the need in the disaster } \\
\text { area. }\end{array}$ \\
\hline Celik (2017) & $\begin{array}{l}\text { Disaster- } \\
\text { related }\end{array}$ & - & - & $\begin{array}{l}\text { Probabilistic } \\
\text { distribution and } \\
\text { deterministic }\end{array}$ & $\begin{array}{l}\text { A decision model } \\
\text { based on fuzzy } \\
\text { method and } \\
\text { DEMATEL. }\end{array}$ & $\begin{array}{l}\text { Supports decision on } \\
\text { the finding temporary } \\
\text { locations for } \\
\text { evacuation for efficient } \\
\text { disaster management. }\end{array}$ \\
\hline $\begin{array}{l}\text { Chen et al. } \\
(2012)\end{array}$ & Generic & - & - & Deterministic & $\begin{array}{l}\text { A framework based } \\
\text { response strategy }\end{array}$ & $\begin{array}{l}\text { Supports decision } \\
\text { making for developing } \\
\text { an appropriate } \\
\text { response plan }\end{array}$ \\
\hline $\begin{array}{l}\text { Davis et al. } \\
\text { (2013) }\end{array}$ & Hurricane & $\begin{array}{l}\text { Cost of } \\
\text { distribution }\end{array}$ & - & Stochastic & $\begin{array}{l}\text { Single objective } \\
\text { programming. Post- } \\
\text { incident distribution } \\
\text { is analyzed in the } \\
\text { second stage of the } \\
\text { two-stage model. }\end{array}$ & \\
\hline $\begin{array}{l}\text { Fancello et } \\
\text { al. (2017) }\end{array}$ & General & $\begin{array}{l}\text { Allocation } \\
\text { of } \\
\text { emergency } \\
\text { vehicles for } \\
\text { evacuation } \\
\text { of victims }\end{array}$ & Single & Stochastic & Two stage model & $\begin{array}{l}\text { Supports decision } \\
\text { making for developing } \\
\text { the allocation through } \\
\text { the choice of shortest } \\
\text { route in order to } \\
\text { develop and efficient } \\
\text { response plan. }\end{array}$ \\
\hline $\begin{array}{l}\text { Ju et al. } \\
(2012)\end{array}$ & Generic & - & - & Stochastic & $\begin{array}{l}\text { Fuzzy AHP and 2- } \\
\text { tuple linguistic } \\
\text { approach }\end{array}$ & $\begin{array}{l}\text { Supports the } \\
\text { development of } \\
\text { capability framework } \\
\text { for an organization }\end{array}$ \\
\hline $\begin{array}{l}\text { Khayal et al. } \\
\text { (2015) }\end{array}$ & General & $\begin{array}{l}\text { Logistics } \\
\text { and } \\
\text { deprivation } \\
\text { costs for } \\
\text { both } \\
\text { prepositioni } \\
\text { ng and post- } \\
\text { disaster } \\
\text { distribution }\end{array}$ & Single & $\begin{array}{l}\text { Stochastic } \\
\text { scenarios }\end{array}$ & $\begin{array}{l}\text { Single objective } \\
\text { programming, multi- } \\
\text { period solution }\end{array}$ & \\
\hline
\end{tabular}




\begin{tabular}{|c|c|c|c|c|c|c|}
\hline Authors & Context & $\begin{array}{l}\text { Objectives } \\
\text { used }\end{array}$ & $\begin{array}{l}\text { Single or } \\
\text { multiple } \\
\text { objective } \\
\text { functions }\end{array}$ & $\begin{array}{l}\text { Data types } \\
\text { Deterministic/ } \\
\text { Stochastic }\end{array}$ & Solution Method & $\begin{array}{c}\text { Information system/ } \\
\text { Remarks }\end{array}$ \\
\hline $\begin{array}{l}\text { Laakso and } \\
\text { Palomäki } \\
\text { (2013) }\end{array}$ & Generic & - & - & - & $\begin{array}{l}\text { Collaborative } \\
\text { framework by } \\
\text { considering various } \\
\text { common issues on } \\
\text { disaster event }\end{array}$ & $\begin{array}{l}\text { Supports policy } \\
\text { development for high- } \\
\text { level collaboration }\end{array}$ \\
\hline $\begin{array}{l}\text { Lee et al. } \\
\text { (2012) }\end{array}$ & $\begin{array}{l}\text { Data on } \\
\text { various } \\
\text { disaster } \\
\text { response or } \\
\text { planning } \\
\text { related } \\
\text { document }\end{array}$ & - & - & Deterministic & $\begin{array}{l}\text { Development of } \\
\text { framework by } \\
\text { synthesizing the data } \\
\text { and extracting the } \\
\text { knowledge for } \\
\text { disaster response }\end{array}$ & $\begin{array}{l}\text { Supports decision } \\
\text { making through a } \\
\text { case-based knowledge } \\
\text { flow model. }\end{array}$ \\
\hline $\begin{array}{l}\text { Peng et al. } \\
(2011)\end{array}$ & $\begin{array}{l}\text { Disaster- } \\
\text { related to } \\
\text { weather }\end{array}$ & - & - & Deterministic & $\begin{array}{l}\text { Data mining and } \\
\text { multiple criteria } \\
\text { method }\end{array}$ & $\begin{array}{l}\text { Interactive } \\
\text { information } \\
\text { management } \\
\text { framework }\end{array}$ \\
\hline $\begin{array}{l}\text { Reniers et al. } \\
(2011)\end{array}$ & $\begin{array}{l}\text { Chemical } \\
\text { plants }\end{array}$ & - & - & $\begin{array}{l}\text { Deterministic } \\
\text { and scenario } \\
\text { based }\end{array}$ & $\begin{array}{l}\text { Use of real option } \\
\text { theory }\end{array}$ & $\begin{array}{l}\text { Obtain economically } \\
\text { justified shutdown } \\
\text { time for each } \\
\text { installation }\end{array}$ \\
\hline $\begin{array}{l}\text { Wei et al. } \\
\text { (2012) }\end{array}$ & $\begin{array}{l}\text { Related to } \\
\text { medical } \\
\text { supplies }\end{array}$ & - & - & $\begin{array}{l}\text { Deterministic } \\
\text { but scenario } \\
\text { based }\end{array}$ & $\begin{array}{l}\text { Rough set theory by } \\
\text { considering various } \\
\text { site based } \\
\text { conditions. }\end{array}$ & - \\
\hline $\begin{array}{l}\text { Zhong et al. } \\
\text { (2010) }\end{array}$ & $\begin{array}{l}\text { Urban areas } \\
\text { related } \\
\text { events }\end{array}$ & - & - & Stochastic & $\begin{array}{l}\text { Petri Net based } \\
\text { system for analysis } \\
\text { of the system }\end{array}$ & $\begin{array}{l}\text { Supports the } \\
\text { integration of } \\
\text { communication } \\
\text { between local and } \\
\text { external emergency } \\
\text { agencies for effective } \\
\text { disaster response }\end{array}$ \\
\hline
\end{tabular}

Table 2. Modeling frameworks for reactive measures

\subsection{Corrective (Recovery) Phase}

Corrective actions are usually taken after the disaster in order to recover it as fast as possible. Chen et al. (2012) mention that in the post-incident stage, the focus is on complete recovery and bringing the situation to normal or to an enhanced level of performance. The review here is focused on the post-disaster situation and response mechanisms. It is to note that some of the literature mentioned in the earlier phases also consider the reactive phase.

\subsubsection{Facilities}

For post-disaster situation, the larger the time required to wait for the relief supplies, more the suffering of the individual people and more impact on the industrial facilities. Therefore, quick analysis and restoration of facilities become important for disaster management.

Ben-Tal, Do-Chung, Mandala and Yao (2011) considered demand uncertainty in relief supplies and proposed a multi-period robust optimization (RO) and cell transmission model (CTM). Their method provides dynamic optimization for assignment of crisis management and control of road traffic movement with time-based on undefined requirements. 
Tzeng, Cheng and Huang (2007) developed a relief-distribution structure in a multi-objective programming model for relief supplies. The model minimizes the costs of transfer points and travel time and maximizes satisfaction. The authors mentioned that compared to the general (or commercial logistics), in relief supplies fairness of supplies, the temporary installation of facilities, and transfer points for relief supplies should be considered. Relief supplies decisions are urgent and are based on available information, and therefore, they are very dynamic. The authors used fuzzy multiple objective models and simulated scenarios to demonstrate the applicability of the model.

Turğut et al. (2011) developed a DSS for the location of disaster logistics center by using analytic hierarchy/fuzzy analytic hierarchy process. Identification of the principles and sub-parameters needed for the suggested DSS was done through a survey completed by experts. The authors mentioned that for the choice of such a center, decisionmakers should consider costs related to investment, operation and maintenance, cost of transportation by mode (air, sea, or land), infrastructure available (IT, energy and water), location (closeness to the city and the disaster location), and the climatic conditions.

\subsubsection{Resources}

Nivolianitou and Synodinou (2011) identified factors influencing response to disasters based on feedback from emergency system documents analysis, interview with experts, official organization, and volunteers. The study identified 15 factors influencing disaster management, which are: role framing (executing activities of the organizations and the capabilities of its employees), competence, availability, intervention type, means, guidelines, cooperation degree, coordination degree, early reaction time, timely information passage, role clearness (exact information of team's member accountability), number of people, deeper contextual knowledge (associated information of disaster situation attributes), organization identity (institute's identification), and cognitive lock-up (readiness of the staff to take care of limited kind of incidents). Also, the study identified two main human factors for consideration: personal factors (the physical fitness, team gender, good memory, stress, fear, perception capacity, attention, temper, character, and motivation), and labor factors (years of experience, time pressure, and workload). The study also identified a group of factors for suitable activities and effective involvement with emphasis on operation and logistic related parameters. One of the major findings of the study is that the importance of human factors evaluation needs to be seriously considered starting from physical condition till workload and capacity. The quantification of these factors and the establishment of required minimum levels are very important elements for disaster response but they are not covered in this study.

In the area of human resources behavior and performance, Subramaniam, Ali and Mohd-Shamsudin (2010) mentioned that disaster response is a collective team effort; therefore, team level analysis becomes important. Their research focuses on team member resources like members' ability, personality, and characteristics of team members (age, tenure, leadership, roles, and norms).

Zhou, Huang and Zhang (2011) presented a tool to evaluate cause-and-effect relationship in disaster management. The authors used fuzzy DEMATEL method to obtain five important critical success factors (CSFs) from a list of 20 interdependent factors. The CSFs consist of four cause elements and one effect element which are: i) sensible organization arrangement and comprehensive knowledge of roles and accountabilities of each individual; ii) efficient emergency communication system to guarantee information transmitting; iii) unified governmental management to integrate design and execution; iv) utilization of up-to-date transportation techniques, and v) continual enhancement of working arrangement of disaster management. The study mentions that continuous improvement of operational aspects is important for an effective disaster management.

Chiu and Zheng (2007) proposed a cells transformation technique (CTM) based linear programming model for the mobilization of tools and equipment, determination of best traffic route, and dispatch timing for multi-priority groups (SMDTS-MPG) for an instantaneous or no-notice disaster. The authors recommended an integrated and multi-dimension evacuation and relief supplies distribution system in order to deploy the resources. The model minimizes the travel time of multi-priority groups over the planning horizon. The result of the model provides travel time, traffic assignment, and departure schedule for different groups.

Vescoukis, Doulamis and Karagiorgou (2012) proposed an environment information management system (EIM) for crisis management and planning based on 3D modeling software. The model is based on the real-time and 
stored information. The proposed model focuses mainly on systems architecture to support environmental simulation on the geospatial information for disaster response and decision support.

De Maio, Fenza, Gaeta, Loia and Orciuoli (2011) proposed a DSS framework based on a fuzzy cognitive map (FCM). The FCM helps in information processing and resources identification based on the disaster situation. The framework consists of several interactive components that are run by emergency managers. The manager provides inputs and directives to the framework and receives system outputs and stimuli (such as messages or phone calls). Stimuli signals either start the DSS session or adapt to a particular disaster plan that exists in the system. In the fuzzy cognitive mapping process, three parts need to be considered, features of the situation, types of actions that match the features and the type of resources required. The authors simulated scenarios by analyzing features, actions, and resources at different time periods. The authors mention that the use of FCM and simulation support decision-making at a very short period of time.

Chen, Peña-Mora and Ouyang (2011) presented a GIS-based framework to allocate equipment required to respond to disasters. The proposed framework consists of three components: emergency resource repository portal (E2RP), mobile resource request client (MR2C), and automated resource management system (ARMS). The authors mention of the need for a repository model in the form of database in the DSS. The use of GIS in ARMS helped to provide routes that take minimum time from a set of location to the disaster site.

In terms of resources (tool, equipment, and distribution), de la Torre et al. (2012) provided an analysis on selected models used in disaster relief routing. The author's review covered a wide span of research areas that support disaster management. The review included policies, demand assessment, uncertainty in supply and demand, vehicles routing, modeling vehicle depot, specialized models, commodities delivery and location, vehicle fleet type and technology, and finally, the uncertainty in the vehicle fleet.

\subsubsection{Support System and Services}

The review of literature in corrective phase is mostly related to flow assignments, planning in anticipation of next disaster, supporting database development, and DSS. The study reviewed here also focus on infrastructure, the behavior of victims, structure of the team, and the policy formulation as well. Therefore, the holistic view becomes important in the corrective phase as the lessons learned in the previous incident can help in developing a better response mechanism for the future.

Park, Hong and Roh (2013) conducted an analysis of Japanese companies that got affected by Tsunami and the restoration of business. The study mentioned four distinct crisis processes in order to recover from such disasters: crisis detection, assessment of damages and required responses, preparation to resume duties, and reexamination of crisis management activities. The authors mentioned two concepts for an efficient disaster management: the emergency supplies delivery system and the emergency supplies network adaptability. The authors conclude that a cooperative databank substructure and supply chain information flow makes the management system more portable and adaptable in disaster situations.

Taber, Plumb and Jolemore (2008) discussed the interaction between the organizational policies and work practices that happen in industrial installations. The authors conducted an empirical study by interviewing emergency response workers (such as firefighters and paramedics) and found that organizational support and collaborative activities with the colleagues in the workplace enhance the learning process beyond the initial training.

There are examples of long-term impact and capabilities analyzed for better disaster response. For example, Nagarajan, Shaw and Albores (2012) focused on communicating warning messages for evacuation. Parlak, Lambert, Guterbock and Clements (2012) used multi-criteria analysis to prioritize the initiatives for different behaviors of disaster victims. Simpson (2008) studied disaster preparedness and response capability for better disaster response by considering factors like public safety, hazard exposure, and city's financial state. Kusumasari, Alam and Siddiqui (2010) mentioned that expertise in assessment of the post-incident situation is important for effective disaster management. Yang and Hsieh (2013) and Oh, Deshmukh and Hastak (2010) recommended having good communication and other support infrastructure for monitoring the available stocks and requirements of supplies for disaster management. 


\subsubsection{Modeling Framework for Corrective Disaster Response}

Table 3 shows various modeling frameworks and DSS based framework in order to support corrective measures or to develop future capabilities to manage disaster responses. The research covered not only the disaster events but it also simulated scenarios and collaborative initiatives among different disciplines related to disaster management. Although various mathematical models can be used to support decision making, the main focus in the corrective phase should be related to the development of policies, training, collaborative joint efforts for disaster management as a culture, a ramped up geospatial database system, and the development of wide range of computer model based disaster scenarios for active interaction by the emergency response units.

\begin{tabular}{|c|c|c|c|c|c|c|}
\hline Authors & Context & $\begin{array}{l}\text { Objectives } \\
\text { used }\end{array}$ & $\begin{array}{l}\text { Single or } \\
\text { multiple } \\
\text { objective } \\
\text { functions }\end{array}$ & $\begin{array}{l}\text { Data types } \\
\text { Deterministic } \\
\text { / Stochastic }\end{array}$ & Solution Method & $\begin{array}{c}\text { Information } \\
\text { system/ Remarks }\end{array}$ \\
\hline $\begin{array}{l}\text { Ben-Tal et al. } \\
\text { (2011) }\end{array}$ & Generic & $\begin{array}{l}\text { Time and } \\
\text { space } \\
\text { dependent } \\
\text { cost for } \\
\text { traffic flow } \\
\text { assignment }\end{array}$ & Single & $\begin{array}{l}\text { Both } \\
\text { Deterministic } \\
\text { and stochastic }\end{array}$ & $\begin{array}{l}\text { Robust } \\
\text { optimization, cell } \\
\text { transmission } \\
\text { model, and affinely } \\
\text { adjustable robust } \\
\text { counterpart }\end{array}$ & - \\
\hline $\begin{array}{l}\text { Chen et al. } \\
\text { (2011) }\end{array}$ & $\begin{array}{l}\text { Civil } \\
\text { engineering } \\
\text { related } \\
\text { response to } \\
\text { the disaster }\end{array}$ & - & - & Deterministic & $\begin{array}{l}\text { Database analysis } \\
\text { and information } \\
\text { protocol for } \\
\text { request and } \\
\text { dispatch of } \\
\text { equipment }\end{array}$ & $\begin{array}{l}\text { Uses GIS for } \\
\text { developing the } \\
\text { fastest route to the } \\
\text { site (from multiple } \\
\text { locations) }\end{array}$ \\
\hline $\begin{array}{l}\text { Chiu and } \\
\text { Zheng (2007) }\end{array}$ & $\begin{array}{l}\text { Urban-based } \\
\text { no-notice } \\
\text { disaster }\end{array}$ & $\begin{array}{l}\text { Minimization } \\
\text { of travel time }\end{array}$ & Single & Stochastic & $\begin{array}{l}\text { Cell transmission } \\
\text { based Linear } \\
\text { programming }\end{array}$ & $\begin{array}{l}\text { Information on } \\
\text { possible routes and } \\
\text { disaster location, but } \\
\text { this is not explicitly } \\
\text { shown. }\end{array}$ \\
\hline $\begin{array}{l}\text { de Maio et al. } \\
(2011)\end{array}$ & Generic & - & - & Deterministic & $\begin{array}{l}\text { Framework, fuzzy } \\
\text { cognitive mapping } \\
\text { and simulation } \\
\text { modeling }\end{array}$ & $\begin{array}{l}\text { DSS with GIS-based } \\
\text { data }\end{array}$ \\
\hline $\begin{array}{l}\text { Subramaniam } \\
\text { et al. (2010) }\end{array}$ & Generic & - & - & $\begin{array}{l}\text { Deterministic/ } \\
\text { behavioral }\end{array}$ & $\begin{array}{l}\text { A team-based } \\
\text { decision for } \\
\text { disaster response }\end{array}$ & $\begin{array}{l}\text { Team structure is } \\
\text { presented }\end{array}$ \\
\hline $\begin{array}{l}\text { Taber et al. } \\
\text { (2008) }\end{array}$ & $\begin{array}{l}\text { Paramedics } \\
\text { and fire } \\
\text { fighter }\end{array}$ & - & - & - & $\begin{array}{l}\text { Survey-based study } \\
\text { for collaborative } \\
\text { work }\end{array}$ & - \\
\hline $\begin{array}{l}\text { Turğut et al. } \\
\text { (2011) }\end{array}$ & Earthquake & - & - & Deterministic & $\begin{array}{l}\text { AHP and fuzzy } \\
\text { AHP for location } \\
\text { of the disaster } \\
\text { relief supply center }\end{array}$ & $\begin{array}{l}\text { Decision support to } \\
\text { help choice of a } \\
\text { location. Can be } \\
\text { applied for use in } \\
\text { industrial facilities }\end{array}$ \\
\hline $\begin{array}{l}\text { Tzeng et al. } \\
(2007)\end{array}$ & Earthquake & $\begin{array}{l}\text { Minimization } \\
\text { of fixed cost, } \\
\text { minimization } \\
\text { of travel } \\
\text { time, } \\
\text { maximization } \\
\text { of } \\
\text { satisfaction }\end{array}$ & $\begin{array}{l}\text { Multi- } \\
\text { objective }\end{array}$ & Deterministic & $\begin{array}{l}\text { Scenario-based and } \\
\text { fully multiple } \\
\text { objective modeling }\end{array}$ & $\begin{array}{l}\text { Electronic location } \\
\text { map for supply } \\
\text { routes. Can be used } \\
\text { in industrial facilities. }\end{array}$ \\
\hline
\end{tabular}




\begin{tabular}{|l|l|l|l|l|l|l|}
\hline \multicolumn{1}{|c|}{ Authors } & \multicolumn{1}{|c|}{ Context } & $\begin{array}{c}\text { Objectives } \\
\text { used }\end{array}$ & $\begin{array}{l}\text { Single or } \\
\text { multiple } \\
\text { objective } \\
\text { functions }\end{array}$ & $\begin{array}{l}\text { Data types } \\
\text { Deterministic } \\
\text { / Stochastic }\end{array}$ & Solution Method & \multicolumn{1}{|c|}{$\begin{array}{l}\text { Information } \\
\text { system/ Remarks }\end{array}$} \\
\hline $\begin{array}{l}\text { Vescoukis et } \\
\text { al. (2012) }\end{array}$ & $\begin{array}{l}\text { Generic, fire } \\
\text { hazard } \\
\text { discussed }\end{array}$ & - & - & Deterministic & $\begin{array}{l}\text { Systems } \\
\text { architecture for } \\
\text { planning and } \\
\text { simulation } \\
\text { modeling }\end{array}$ & $\begin{array}{l}\text { Expected as a } \\
\text { decision support } \\
\text { system with } \\
\text { integration of } \\
\text { geospatial data } \\
\text { system }\end{array}$ \\
\hline $\begin{array}{l}\text { Yaming et al. } \\
(2011)\end{array}$ & $\begin{array}{l}\text { Petrochemica } \\
\text { industry }\end{array}$ & - & - & Deterministic & $\begin{array}{l}\text { Simulation of gas } \\
\text { dispersion and } \\
\text { heuristics for } \\
\text { routing }\end{array}$ & GDSS based on GIS \\
\hline $\begin{array}{l}\text { Zhou et al. } \\
(2011)\end{array}$ & $\begin{array}{l}\text { Natural } \\
\text { disasters }\end{array}$ & - & - & Stochastic & $\begin{array}{l}\text { Fuzzy DEMATEL } \\
\text { method }\end{array}$ & $\begin{array}{l}\text { The focus is on } \\
\text { finding the critical } \\
\text { success factors for } \\
\text { disaster management }\end{array}$ \\
\hline
\end{tabular}

Table 3. Models and framework for corrective measures

\section{Conclusions and Research Opportunities}

Disaster in industrial cities does not only consider social aspects that involve casualty and displacement of people, but it also involves economic losses due to the loss of capital assets and loss of revenues. Additionally, it would also damage the geography around the disaster site. Disaster in the industrial city becomes important because of the complexity of the processes handled and materials stored in the premises, which may not only impact the disaster triggering industrial facility, but it may cause more damages in the neighboring facilities as well. Therefore, many researchers have been working in different phases of disaster management for preplanning, responding or providing corrective measures. The literature review presented in this paper shows that considerable work has been done in understanding, planning, and preparing for the disaster situation. However, disaster management in industrial cities should focus not only on the facility-based process and material characteristics, shutdown, and evacuation but it should also focus on the industrial city based routing of evacuation, sheltering the evacuated people for a short-term, protecting the facility and its neighborhood to avoid the resulting disaster. Ramli, Mokhtar and Aziz (2014) also emphasize the importance of multi-facility safety or cluster-based safety. The combination of various facility-based and city-based factors for an integrated disaster management is not found in the literature.

We find that modeling for preplanning and localization of response depending on the nature of the area (spatial and technical), and the capability of the response mechanism are the most important factors to decrease the impact on people, business, and infrastructure. This type of planning should be done on a cyclic basis by incorporating the lessons learned, improved mathematical frameworks, and the technology.

\subsection{Research Opportunities}

In terms of future research, we propose three high-level directions. Each of these directions can be supported by smaller and focused research mentioned therein. The focus of research should be to increase economic efficiency in the planning phase and service efficiency during and post-incident phase.

1. Research should be carried out in an industrial area in terms of assessing the impact of no-notice or known disasters. Various networking models can help to identify the locations for sheltered supplies, evacuation facilities, evacuation routes and evacuation modes. As disaster response should focus on response actions rather than on the costs. Mathematical models (exact and heuristics) and simulation models should be developed for the rigorous planning of disaster response.

2. Research in the industrial cities are usually focused at the individual plant level and is scaled up to the industrial city area level. This is not necessarily right because of the interaction of one industry with the 
other in an industrial city. For example, if the fire started in one location moves to the next location, there might be more damages caused in the next location and the first industry can be left with an insignificant impact. This means that the nature of the environment, the content of the materials handled, stored and processed in a particular installation also becomes important. This might require developing new indices, like toxicity index, for disaster management. The response model requires cooperative model (also called risk pooling) for resources and skills available inside the industrial installations as well. Such a multienterprise collaborative disaster response model, also emphasized by Nof, Morel, Monostori, Molina and Filip (2006), can lead to an effective disaster management system.

3. Another area to focus on research would be to develop a disaster preparedness maturity model. With standardized procedures, full integration with the technology, development of maturity model would help to assess and implement measures for disaster readiness of an organization. This can also help in developing a common understanding of disaster management as emphasized by Laakso and Palomäki (2013).

\subsection{Limitations}

The focus of the review is on highlighting the importance of industrial disaster. The review is limited mainly to the large-scale disaster management, the modeling process or the decision-making process. The content in the literature is focussed mainly on the technical aspects as shown in Figure 2. Aspects like leadership and other managerial aspects, implications of the disaster management in industrial areas, and suitability of the models and frameworks in all industrial areas are not the focus of the literature review. This is mainly due to the lack of extant literature available in the printed media. Therefore, the authors believe that this review will open further opportunity to conduct meaningful research mainly for the preparedness aspects of the disaster management. It should help in realizing that emergency preparedness in an industry by considering both internal and external factors as the core value in the sustainability of industrial establishment and economic benefits.

\section{Declaration of Conflicting Interests}

The authors declared no potential conflicts of interest with respect to the research, authorship, and/or publication of this article.

\section{Funding}

The authors received no financial support for the research, authorship, and/or publication of this article.

\section{References}

Alexander, D. (1997). The study of natural disasters, 1977-97: Some reflections on a changing field of knowledge. Disasters, 21(4), 284-304. https://doi.org/10.1111/1467-7717.00064

Baldini, G., Oliveri, F., Braun, M., Seuschek, H., \& Hess, E. (2012). Securing disaster supply chains with cryptography enhanced RFID. Disaster Prevention and Management: An International Journal, 21(1), 51-70. https://doi.org/10.1108/09653561211202700

Beerens, R.J.J., \& Tehler, H. (2016). Scoping the field of disaster exercise evaluation-A literature overview and analysis. International Journal of Disaster Risk Reduction, 19, 413-446. https://doi.org/10.1016/j.ijdrr.2016.09.001

Benet-Zepf, A., Marin-Garcia, J.A., \& Küster, I. (2018). Clustering the mediators between the sales control systems and the sales performance using the amo model: A narrative systematic literature review. Intangible Capital, 14(3), 387-408. http://dx.doi.org/10.3926/ic.1222

Ben-Tal, A., Do-Chung, B., Mandala, S.R., \& Yao, T. (2011). Robust optimization for emergency logistics planning: Risk mitigation in humanitarian relief supply chains. Transportation Research Part B: Methodological, 45(8), 1177-1189.

Calixto, E., \& Larouvere, E.L. (2010). The regional emergency plan requirement: Application of the best practices to the Brazilian case. Safety Science, 48(8), 991-999. https://doi.org/10.1016/j.ssci.2009.06.005 
Caunhye, A.M., Nie, X., \& Pokharel, S. (2012). Optimization models in emergency logistics: A literature review. Socio-Economic Planning Sciences, 46(1), 4-13. https://doi.org/10.1016/j.seps.2011.04.004

Celik, E. (2017). A cause and effect relationship model for location of temporary shelters in disaster operations management. International Journal of Disaster Risk Reduction, 22, 257-268. https://doi.org/10.1016/j.ijdrr.2017.02.020

Chen, A.Y., Peña-Mora, F., \& Ouyang, Y. (2011). A collaborative GIS framework to support equipment distribution for civil engineering disaster response operations. Automation in Construction, 20(5), 637-648.

https://doi.org/10.1016/j.autcon.2010.12.007

Chen, A., Chen, N., \& Li, J. (2012). During-incident process assessment in emergency management: Concept and strategy. Safety Science, 50(1), 90-102. https://doi.org/10.1016/j.ssci.2011.07.006

Chiu, Y.C., \& Zheng, H. (2007). Real-time mobilization decisions for multi-priority emergency response resources and evacuation groups: model formulation and solution. Transportation Research Part E: Logistics and Transportation Review, 43(6), 710-736. https://doi.org/10.1016/j.tre.2006.11.006

Davis, L.B., Samanlioglu, F., Qu, X., \& Root, S. (2013). Inventory planning and coordination in disaster relief efforts. International Journal of Production Economics, 141(2), 561-573. https://doi.org/10.1016/j.ijpe.2012.09.012

de la Torre, L.E., Dolinskaya, I.S., \& Smilowitz, K.R. (2012). Disaster relief routing: Integrating research and practice. Socio-economic Planning Sciences, 46(1), 88-97. https://doi.org/10.1016/j.seps.2011.06.001

de Maio, C., Fenza, G., Gaeta, M., Loia, V., \& Orciuoli, F. (2011). A knowledge-based framework for emergency DSS. Knowledge-Based Systems, 24(8), 1372-1379. https://doi.org/10.1016/j.knosys.2011.06.011

Fancello, G., Mancini, S., Pani, C., \& Fadda, P. (2017). An emergency vehicles allocation model for major industrial disasters. Transportation Research Procedia, 25, 1164-1179. https://doi.org/10.1016/j.trpro.2017.05.134

Granot, H. (1998). The dark side of growth and industrial disasters since the Second World War. Disaster Prevention and Management: An International Journal, 7(3), 195-204. https://doi.org/10.1108/09653569810223281

Holguín-Veras, J., Jaller, M., Van Wassenhove, L.N., Pérez, N., \& Wachtendorf, T. (2012). On the unique features of post-disaster humanitarian logistics. Journal of Operations Management, 30(7), 494-506.

https://doi.org/10.1016/j.jom.2012.08.003

Inoue, Y., \& Havard, C.T. (2015). Sport and disaster relief: a content analysis. Disaster Prevention and Management, 24(3), 355-368. https://doi.org/10.1108/DPM-12-2014-0276

Ju, Y., Wang, A., \& Liu, X. (2012). Evaluating emergency response capacity by fuzzy AHP and 2-tuple fuzzy linguistic approach. Expert Systems with Applications, 39(8), 6972-6981. https://doi.org/10.1016/j.eswa.2012.01.061

Khayal, D., Pradhananga, R., Pokharel, S., \& Mutlu, F. (2015). A model for planning locations of temporary distribution facilities for emergency response. Socio-Economic Planning Sciences, 52, 22-30.

https://doi.org/10.1016/j.seps.2015.09.002

Kusumasari, B., Alam, Q., \& Siddiqui, K. (2010). Resource capability for local government in managing disaster. Disaster Prevention and Management: An International Journal, 19(4), 438-451.

https://doi.org/10.1108/09653561011070367

Laakso, K., \& Palomäki, J. (2013). The importance of a common understanding in emergency management. Technological Forecasting and Social Change, 80(9), 1703-1713. https://doi.org/10.1016/j.techfore.2012.12.012

Lee, W.B., Wang, Y., Wang, W.M., \& Cheung, C.F. (2012). An unstructured information management system (UIMS) for emergency management. Expert Systems with Applications, 39(17), 12743-12758. https://doi.org/10.1016/j.eswa.2012.02.037

Li, L., Jin, M., \& Zhang, L. (2011). Sheltering network planning and management with a case in the Gulf Coast region. International Journal of Production Economics, 131(2), 431-440. https://doi.org/10.1016/j.ijpe.2010.12.013 
Marin-Garcia, J.A., Betancour, E., \& Giraldo-O’Meara, M. (2018). Protocol: Literature review on the psychometric properties of the short versions of the scales of social desirability in the answers to competency self-assessment questionnaires. Working Papers on Operations Management, 9(1), 16. https://doi.org/10.4995/wpom.v9i1.9172

Marin-Garcia, J.A., \& Martinez-Tomas, J. (2016). Deconstructing amo framework: A systematic review. Intangible Capital, 12(4), 1040-1087. http://dx.doi.org/10.3926/ic.838

Moe, T.L., \& Pathranarakul, P. (2006). An integrated approach to natural disaster management: public project management and its critical success factors. Disaster Prevention and Management: An International Journal, 15(3), 396-413. https://doi.org/10.1108/09653560610669882

Mojtahedi, M., \& Oo, B.L. (2017). Critical attributes for proactive engagement of stakeholders in disaster risk management. International Journal of Disaster Risk Reduction, 21, 35-43. https://doi.org/10.1016/j.ijdrr.2016.10.017

Nagarajan, M., Shaw, D., \& Albores, P. (2012). Disseminating a warning message to evacuate: A simulation study of the behaviour of neighbours. European Journal of Operational Research, 220(3), 810-819. https://doi.org/10.1016/j.ejor.2012.02.026

Nivolianitou, Z., \& Synodinou, B. (2011). Towards emergency management of natural disasters and critical accidents: The Greek experience. Journal of Environmental Management, 92(10), 2657-2665. https://doi.org/10.1016/j.jenvman.2011.06.003

Nof, S.Y., Morel, G., Monostori, L., Molina, A., \& Filip, F. (2006). From plant and logistics control to multi-enterprise collaboration. Annual Reviews in Control, 30(1), 55-68. https://doi.org/10.1016/j.arcontrol.2006.01.005

OECD (Organization of Economic Cooperation and Development) (2003). OECD Guiding Principles for Chemical Accident Prevention, Preparedness and Response. Inter-Organization Programme for the Sound Management of Chemicals, Series on Chemical Accidents, 10. Paris, France: OECD Environment, Health and Safety Publications.

Oh, E.H., Deshmukh, A., \& Hastak, M. (2010). Disaster impact analysis based on inter-relationship of critical infrastructure and associated industries: a winter flood disaster event. International Journal of Disaster Resilience in the Built Environment, 1(1), 25-49. https://doi.org/10.1108/17595901011026463

Park, Y., Hong, P., \& Roh, J.J. (2013). Supply chain lessons from the catastrophic natural disaster in Japan. Business Horizons, 56(1), 75-85. https://doi.org/10.1016/j.bushor.2012.09.008

Parlak, A.I., Lambert, J.H., Guterbock, T.M., \& Clements, J.L. (2012). Population behavioral scenarios influencing radiological disaster preparedness and planning. Accident Analysis \& Prevention, 48, 353-362.

https://doi.org/10.1016/j.aap.2012.02.007

Peng, Y., Zhang, Y., Tang, Y., \& Li, S. (2011). An incident information management framework based on data integration, data mining, and multi-criteria decision making. Decision Support Systems, 51(2), 316-327. https://doi.org/10.1016/j.dss.2010.11.025

Ramli, A., Mokhtar, M., \& Aziz, B.A. (2014). The development of an initial framework for multi-firm industrial safety management based on cooperative relationship: A Malaysia case study. International Journal of Disaster Risk Reduction, 10, 349-361. https://doi.org/10.1016/j.ijdrr.2014.10.002

Reniers, G.L., Ale, B.J.M., Dullaert, W., \& Soudan, K. (2009). Designing continuous safety improvement within chemical industrial areas. Safety Science, 47(5), 578-590. https://doi.org/10.1016/j.ssci.2008.07.003

Reniers, G.L., Audenaert, A., Pauwels, N., \& Soudan, K. (2011). Empirical validation of a real options theory based method for optimizing evacuation decisions within chemical plants. Journal of Harardous Materials, 186(1), 779-787. https://doi.org/10.1016/j.jhazmat.2010.11.061

Reniers, G., Khakzad, N., Cozzani, V., \& Khan, F. (2018). The impact of nature on chemical industrial facilities: Dealing with challenges for creating resilient chemical industrial parks. Journal of Loss Prevention in the Process Industries, 56, 378-385. https://doi.org/10.1016/j.jlp.2018.09.010

Seok, H., Nof, S.Y., \& Filip, F.G. (2012). Sustainability decision support system based on collaborative control theory. Annual Reviews in Control, 36(1), 85-100. https://doi.org/10.1016/j.arcontrol.2012.03.007 
Shaluf, I.M., Ahmadun, F.R., Mat-Said, A., Mustapha, S.A., \& Sharif, R. (2002). Technological man-made disaster precondition phase model for major accidents. Disaster Prevention and Management: An International Journal, 11(5), 380-388. https://doi.org/10.1108/09653560210453425

Shen, Y., Wang, Q., Yan, W., \& Wang, J. (2015). A transportation-location problem model for pedestrian evacuation in chemical industrial parks disasters. Journal of Loss Prevention in the Process Industries, 33, 29-38.

https://doi.org/10.1016/j.jlp.2014.11.008

Simpson, D.M. (2008). Disaster preparedness measures: a test case development and application. Disaster Prevention and Management: An International Journal, 17(5), 645-661. https://doi.org/10.1108/09653560810918658

Subramaniam, C., Ali, H., \& Mohd Shamsudin, F. (2010). Understanding the antecedents of emergency response: a proposed framework. Disaster Prevention and Management: An International Journal, 19(5), 571-581. https://doi.org/10.1108/09653561011091904

Taber, N., Plumb, D., \& Jolemore, S. (2008). "Grey" areas and "organized chaos" in emergency response. Journal of Workplace Learning, 20(4), 272-285. https:/ / doi.org/10.1108/13665620810871123

Turğut, B.T., Tas, G., Herekoglu, A., Tozan, H., \& Vayvay, O. (2011). A fuzzy AHP based decision support system for disaster center location selection and a case study for Istanbul. Disaster Prevention and Management: An International Journal, 20(5), 499-520. https://doi.org/10.1108/09653561111178943

Tzeng, G.H., Cheng, H.J., \& Huang, T.D. (2007). Multi-objective optimal planning for designing relief delivery systems. Transportation Research Part E: Logistics and Transportation Review, 43(6), 673-686. https://doi.org/10.1016/j.tre.2006.10.012

UNEP (United Nations Environment Programme) (2010). A Flexible Framework for Addressing Chemical Accident Prevention and Preparedness: A Guidance Document. Inter-Organization Programme for the Sound Management of Chemicals, United Nations Environment Programme Division of Technology, Industry and Economics (UNEP DTIE). Paris, France: Sustainable Consumption and Production (SCP) Branch.

Vescoukis, V., Doulamis, N., \& Karagiorgou, S. (2012). A service oriented architecture for decision support systems in environmental crisis management. Future Generation Computer Systems, 28(3), 593-604.

https://doi.org/10.1016/j.future.2011.03.010

Van Wassenhove, L.N. (2006). Blackett memorial lecture. Humanitarian aid logistics: Supply chain management in high gear. Journal of the Operational Research Society, 57(5), 475-489. https://doi.org/10.1057/palgrave.jors.2602125

Wei, X., Qiuyan, S., \& Jinlong, L. (2012). The group decision-making rules based on rough sets on large scale engineering emergency. Systems Engineering Procedia, 4, 331-337.

Yaming, M., Ming, L., Weidong, D., \& Hongkun, C. (2011), September. Study on emergency decision support system of toxic gas release based on GIS. In Electronics, Communications and Control (ICECC), International Conference (3926-3929). IEEE. https://doi.org/10.1109/ICECC.2011.6068017

Yang, T.K., \& Hsieh, M.H. (2013). Case analysis of capability deployment in crisis prevention and response. International Journal of Information Management, 33(2), 408-412. https://doi.org/10.1016/j.ijinfomgt.2012.10.010

Yoon, S.W., Velasquez, J.D., Partridge, B.K., \& Nof, S.Y. (2008). Transportation security decision support system for emergency response: A training prototype. Decision Support Systems, 46(1), 139-148.

https://doi.org/10.1016/j.dss.2008.06.002

Zhao, Q., Huang, Q., Guo, J., \& Zhu, H. (2008), October. Integrated Risk Assessment of Hazardous Chemical Installations Using GIS and AHP. In 4th International Conference on Wireless Communications, Networking and Mobile Computing (1-5). IEEE. https://doi.org/10.1109/WiCom.2008.2472

Zhong, M., Shi, C., Fu, T., He, L., \& Shi, J. (2010). Study in performance analysis of China Urban Emergency Response System based on Petri net. Safety Science, 48(6), 755-762. https://doi.org/10.1016/j.ssci.2010.02.017

Zhou, Q., Huang, W., \& Zhang, Y. (2011). Identifying critical success factors in emergency management using a fuzzy DEMATEL method. Safety Science, 49(2), 243-252. https://doi.org/10.1016/j.ssci.2010.08.005 
Zio, E., \& Aven, T. (2013). Industrial disasters: Extreme events, extremely rare. Some reflections on the treatment of uncertainties in the assessment of the associated risks. Process Safety and Environmental Protection, 91(1), 31-45. https://doi.org/10.1016/j.psep.2012.01.004

Journal of Industrial Engineering and Management, 2019 (www.jiem.org)

\section{() $(1) \Theta$}

Article's contents are provided on an Attribution-Non Commercial 4.0 Creative commons International License. Readers are allowed to copy, distribute and communicate article's contents, provided the author's and Journal of Industrial Engineering and Management's names are included. It must not be used for commercial purposes. To see the complete license contents, please visit https://creativecommons.org/licenses/by-nc/4.0/. 